\title{
Clarice Della Torre Ferrarini: o depoimento de uma pioneira da administração em enfermagem no Brasil
}

\author{
Clarice Della Torre Ferrarini: the testimony \\ of a pioneer in nursing management \\ in Brazil
}

Para consulta ao depoimento, Centro de Documentação da Escola de Enfermagem Anna Nery, Universidade Federal do Rio de Janeiro.

\author{
Maria Cristina Sanna \\ Professora da Universidade de Santo Amaro, São Paulo. \\ Rua Capote Valente, 154, ap. 43 \\ 05409-000 São Paulo - SP Brasil \\ mcsanna@uol.com.br
}

\begin{abstract}
SANNA, M. C.: 'Clarice Della Torre Ferrarini: o depoimento de uma pioneira da administração em enfermagem no Brasil'. História, Ciências, Saúde-Manguinhos, vol. 10(3): 1053-70, set.-dez. 2003.

O presente depoimento, construído a partir de entrevistas realizadas nos anos de 1996 e 1997 com a enfermeira Clarice Della Torre Ferrarini, por ocasião da coleta de dados para a tese de doutoramento intitulada História de Enfermeiras gerentes: subsídios para a compreensão de um modelo-referência de organização de serviços de enfermagem no período de 1950 a 1980, é apresentado após ter sido submetido aos processos de transcrição, validação e autorização. O processo é descrito e exemplificado, e o produto apresentado evidencia a trajetória da entrevistada, desde a escolha da profissão até o desempenho de vários papéis profissionais de liderança no cenário da administração em enfermagem, em cinqüenta anos de vida profissional vinculada a instituições como o Hospital das Clínicas de São Paulo, o Ministério da Saúde e a Associação Brasileira de Enfermagem, entre outras.
\end{abstract}

PALAVRAS-CHAVE: história, enfermagem, administração.

SANNA, M. C.: 'Clarice Della Torre Ferrarini: the testimony of a pioneer in nursing management in Brazil'. História, Ciências, Saúde - Manguinhos, vol. 10(3): 1053-70, Sept.-Dec. 2003.

This testimony is drawn from interviews conducted with the nurse Clarice Della Torre Ferrarini in 1996 and 1997 as part of data collection for the doctoral dissertation entitled History of nurse managers: subsidies for an understanding of a reference model on the organization of nursing services from 1950 through 1980 (História de Enfermeiras gerentes: subsídios para a compreensão de um modelo-referência de organização de serviços de enfermagem no período de 1950 a 1980). The article describes and exemplifies the process of transcription, validation, and authorization to which these interviews were submitted. The product reveals the interviewee's trajectory from the time she chose her profession through her performance of a series of leadership roles within the realm of nursing management, covering a career of fifty years at institutions such as São Paulo's Hospital das Clinicas, the Brazilian Ministry of Health, and the Brazilian Nursing Association, among others.

KEYWORDS: history, nursing, management. 
C larice Della Torre Ferrarini nasceu em 20 de novembro de 1921, em São José do Rio Pardo, estado de São Paulo. Filha de administrador de fazenda, após completar o curso ginasial, em 1939, em plena Segunda Guerra Mundial, foi estudar enfermagem na Escola de Enfermagem Anna Nery, da Universidade do Brasil (EEAN), ${ }^{1}$ de $1^{\circ}$ de agosto de 1940 a 6 de setembro de 1943. Tendo sido recomendada por Laís Neto dos Reys, ${ }^{2}$ diretora da EEAN, para trabalhar com a madre Domineuc $^{3}$ no Hospital São Paulo, chegou a se apresentar para a entrevista, mas preferiu trabalhar no Hospital das Clínicas da Faculdade de Medicina da Universidade de São Paulo (HCFMUSP) ${ }_{,}^{4}$ que ainda não estava concluído. Para tanto, procurou a diretora da enfermagem do hospital, Hilda Krish, ${ }^{5}$ que fora aluna da EEAN.

Assim, Clarice iniciou suas atividades no HCFMUSP em janeiro de 1944, por indicação da diretora da Escola de Enfermagem anexa à Faculdade de Medicina da Universidade de São Paulo (EEUSP), Edith de Magalhães Fraenkel, ${ }^{6}$ para onde fora contratada como professora da disciplina fundamentos de enfermagem.

Quando o hospital recebeu o primeiro doente, ela pediu para integrar o corpo de funcionários, desejo viabilizado por Enéas de Carvalho Aguiar, primeiro superintendente do HCFMUSP e parente do governador à época, Fernando Costa. Em novembro de 1944, foi designada assistente da diretoria de Enfermagem e, em maio de 1945, assumiu a diretoria da Subdivisão de Enfermagem do HCFMUSP. De 1953 a 1954, fez um estágio de um ano no Columbia University Teacher's College nos Estados Unidos, com o apoio da Kellogg Foundation, com ênfase em administração em enfermagem. Recepcionou a enfermeira Eleonor Lambertsen ${ }^{8}$ quando esta veio ao Brasil ministrar o curso de team work (trabalho em equipe), do qual Clarice foi tradutora.

Com a separação entre a Escola de Enfermagem e o HCFMUSP, no início de sua gestão como diretora no hospital, Clarice promoveu a definição e a implantação de normas e técnicas básicas que iriam regulamentar a enfermagem na instituição. Também participou dos cursos de administração hospitalar ministrados pela Faculdade de Saúde Pública da USP, ' sob a coordenação de Odair Pacheco Pedroso. Durante os 24 anos em que liderou a enfermagem do Hospital das Clínicas da FMUSP, até sua aposentadoria, em 1969, participou de eventos marcantes na história da instituição, como os primeiros transplantes cardíaco e renal efetuados no país.

Ela foi responsável pela implantação da primeira Unidade de Terapia Intensiva no Pronto-Socorro, do Centro de Recuperação Pós-Anestésica, da Unidade de Treinamento e Desenvolvimento de Pessoal, ${ }^{10}$ denominada Educação em Serviço, e fez a proposta para a implantação da primeira Comissão de Infecção Hospitalar daquela instituição. Sob sua coordenação, foram elaborados o primeiro regulamento da subdivisão de enfermagem e os manuais de educação em serviço e do servidor do HCFMUSP. Atuou como assistente técnica da 
superintendência do mesmo hospital, de 1969 a 1983, e assistente técnica da diretoria clínica, de 1983 a 1993, quando se afastou do serviço público.

Foi ainda assistente técnica de direção no Hospital Cruzada PróInfância, de 1957 a 1958, e do Hospital Infantil Morumbi, depois denominado Darcy Vargas, de 1958 a 1963. De 1978 a 1980, foi diretora da Divisão Nacional de Organização de Serviços de Saúde no Ministério da Saúde, quando coordenou a elaboração da publicação Padrões Minimos de Enfermagem ${ }^{11}$ e participou das primeiras definições das normas para a construção de estabelecimentos de saúde. ${ }^{12}$ Teve destacada atuação na criação dos conselhos Federal de Enfermagem e Regional de São Paulo, tendo sido uma das conselheiras da primeira diretoria. ${ }^{13}$ Além disso, teve expressiva participação na Associação Brasileira de Enfermagem (ABEn), da qual foi presidente de 1962 a 1964 e vice-presidente no biênio seguinte, período marcado pela remodelação da Revista Brasileira de Enfermagem, ${ }_{14}^{14}$ pela criação do curso de formação do técnico de enfermagem, ${ }^{15}$ pelas discussões sobre a conservação do status de profissional liberal e de mudança da sede da entidade para Brasília. ${ }^{16}$

Eleita enfermeira do ano de $1969^{17}$ pela Johnson \& Johnson's, desenvolveu trabalhos de assessoria para a empresa, ministrando cursos em várias cidades brasileiras. Recebeu várias outras homenagens, entre as quais se destacam o título de Cidadão Emérito de São José do Rio Pardo e as organizadas na Cidade do Cabo, pelo famoso cirurgião cardíaco Christian Barnard para a equipe do professor Euriclydes de Jesus Zerbini, da qual fez parte. Também representou a enfermagem brasileira em organismos internacionais como a Associação Internacional Católica de Enfermeiras e Assistentes Médico-Sociais (Ciciams) e o International Council of Nursing (ICN).

\section{Uma explicação sobre a construção do depoimento}

As entrevistas empregadas na construção do presente depoimento foram realizadas entre setembro de 1996 e fevereiro de 1997 pela autora deste artigo, por ocasião da coleta de dados para sua tese de doutoramento. A gravação foi feita em fita magnética e transcrita pela pesquisadora, e o texto foi submetido à entrevistada. Nessa transcrição, necessária para a análise dos dados, procurou-se resguardar a fidelidade à narração, registrando-se, por meio de sinais gráficos, a interrupção de palavras, frases ou parágrafos. O texto resultante foi submetido à entrevistada, antes do encontro seguinte, para que pudesse lê-lo com vagar e julgar a oportunidade de complementar ou alterar as informações fornecidas.

Quando pedido pela narradora, cópia da gravação lhe foi franqueada para comparação. Esgotada a narrativa, encerrou-se a coleta de dados com a assinatura de termo de consentimento pós-informação e rubrica 
das páginas da transcrição, da qual já fora excluída a parte da narração vetada ou substituída pela entrevistada. O procedimento foi necessário para dar cumprimento aos preceitos éticos e legais sobre a pesquisa com seres humanos e para que a narradora assegurasse à pesquisadora os detalhes de sua explanação que concordava em ver publicados. $\mathrm{O}$ documento foi assinado em três vias pela entrevistada, pela pesquisadora e por sua orientadora, tendo uma via ficado em poder desta última, e as demais, com a pesquisadora.

A seguir procedeu-se ao que Gattaz (1996, pp. 135-40) conceitua como 'transcriação': a ação que surge da necessidade de reformular a transcrição literal para torná-la compreensível à leitura. Na opinião daquela estudiosa, a transcriação é um processo no qual se procura corrigir a desigualdade existente entre o código oral e o código escrito, por meio da retirada de palavras, frases e parágrafos ou sua alteração/ acréscimo, em busca de que o não literalmente dito seja dito, e o dito seja compreendido.

Como método para a transcriação, Gattaz prescreve etapas que foram observadas pela pesquisadora na execução do presente trabalho: a transcrição literal, a primeira textualização, a codificação e a indexação, a segunda textualização e a conferência e legitimação.

A primeira dessas ações consiste na versão da palavra falada para a palavra escrita, realizada com a ajuda da escuta da fita gravada. Ela deve ser o mais completa e rigorosa possível, registrando-se, através de sinais gráficos, a interrupção das palavras, frases ou parágrafos e outras características da entrevista, como já descrito.

A segunda ação consiste na incorporação das perguntas à fala do depoente, quando cada parágrafo é transcriado para ficar mais compreensível. Nessa etapa, se necessário, são aproximados os textos das narrativas que se referem ao mesmo tema, para que se facilite a compreensão da linha de raciocínio do narrador. De fato, a linguagem oral se apresenta sob outra lógica, podendo-se, sem prejuízo do entendimento do interlocutor, ir e voltar no assunto. Já na linguagem escrita, é preciso empregar outro ritmo e estrutura, ainda mais porque ela não pode ser complementada com a expressão corporal ou com a entonação das palavras e frases, recursos que colaboram na compreensão da comunicação oral.

Apesar da dificuldade de exemplificar como isso foi feito, aqui se demonstra o procedimento a partir de uma pequena amostra. A transcrição literal da gravação é a seguinte:

E na psiquiatria, também, eu me lembro quando a psiquiatria começou a funcionar, eu tinha chegado dos Estados Unidos em 54 (nós fomos e voltamos em 54)... Eu sei que eu estava com a matéria na cabeça assim, bastante fresca, bastante. A gente tinha tido aula no Columbia University Teacher's College, então a gente estava bem atualizada, se bem que eu questionava muito com o professor ... Como se chama esse professor que saiu de lá? Esqueci 
o nome dele agora. Então, ele realmente, a idéia de psiquiatria dele ainda era do doente ficar amarrado, dentro do quarto, aquele jeito assim. Eu então questionava, porque estava chegando dos Estados Unidos com idéia tão fresquinha de coisas boas da psicologia, no tratamento do paciente e tudo, então questionava. Então, a gente tinha problemas às vezes ou outra no questionamento de colocação, onde colocar, se põe separado... E eles ainda não conheciam essa enfermagem, mas tinham que aceitar um questionamento da enfermagem. Na clínica obstétrica também, eu me lembro que eu questionava tanto sobre as coisas que ele queria fazer, e eu ... que um dia, ele comentando no conselho, que queria dar um piparote na minha touca (risos) porque eu era muito imponente. Então, às vezes, essas pessoas se incomodavam com a arrogância, não digo arrogância, mas com a colocação que eu fazia. Então eu acho que eu realmente, eu criei, não criei caso, mas sempre fui uma pessoa que teve uma oportunidade de manifestação do meu ponto de vista e tudo, né?

\section{A transcriação ficou assim:}

Eu me lembro que, quando a clínica de psiquiatria começou a funcionar em 1954, nós havíamos acabado de chegar dos Estados Unidos. Passamos uma temporada daquele ano no Columbia University Teacher's College e estávamos bem atualizadas. Questionávamos muito o professor que já saiu de lá, de quem, no momento, não me recordo o nome, porque a idéia de psiquiatria dele ainda era do doente ficar amarrado, dentro do quarto, daquele jeito antigo. Eu então questionava, porque havia acabado de chegar dos Estados Unidos, onde tinha adquirido conhecimentos recentes de psicologia sobre o tratamento do paciente, e enfrentava dificuldades quando questionava sobre a acomodação do paciente, sua separação dos demais etc. Também me lembro de ter questionado tanto algumas coisas que o professor queria fazer na clínica obstétrica, que um dia, comentando o fato na reunião do Conselho Deliberativo, ele disse que queria dar um piparote na minha touca porque eu era muito imponente. Então, às vezes essas pessoas se incomodavam, não digo que com a arrogância, mas com as colocações que eu fazia. Eu não acho que eu tenha sido uma "criadora de casos", mas reconheço que sempre aproveitei as oportunidades que tive para manifestar o meu ponto de vista.

A seguir passou-se à terceira etapa. Vários estudos que empregam a história oral como método utilizam o próprio julgamento do depoente como recurso para a legitimação dos procedimentos até aqui descritos, e esta seria uma das possibilidades para o presente trabalho. Há autores, no entanto, que ponderam sobre a pertinência dessa conduta frente a depoentes que, por meio de "cortes e correções efetuados nas transcrições, ocultaram para sempre eventos, impressões, enfim, uma história plena de confrontos, descontinuidades e decepções" (Janotti, 
1996, p. 58). Por essas razões, diferentemente do que propôs Gattaz (1996, p. 138), a legitimação do texto pela entrevistada não se deu no fim do processo, e sim logo após a transcrição literal, o que gerou a necessidade de se buscarem outros recursos para superar esse limite e garantir o rigor.

Para resolver essa dificuldade, contou-se com a colaboração de outro pesquisador que acompanhou todo o processo de transcriação, comparando as transcrições literais das entrevistas aos relatos organizados pela autora do presente estudo, indagando sempre que percebesse omissões, acréscimos e interpretações não desejáveis. Depois dessa avaliação, as narrativas foram compactadas e o texto resultante das transcriações foi rearranjado de forma a resultar numa seqüência que permitisse a fluidez da leitura. Assim se considerou encerrada a segunda textualização e cumprida a etapa de conferência e legitimação, podendose então apreciar o depoimento.

\section{O depoimento}

Eu sou de uma cidade pequena, do interior de São Paulo chamada São José do Rio Pardo, onde viveu Euclides da Cunha, ${ }^{18}$ que sempre foi reverenciado na cidade. Completei o curso ginasial na época da Segunda Grande Guerra e, tendo ouvido falar sobre as enfermeiras que cuidavam dos feridos, interessei-me pela profissão. Creio que posso associar os fatos que ouvi com o hábito de meus pais de cuidar de pessoas que estivessem doentes e à presença de médicos que vinham à fazenda que meu pai administrava, para prestar assistência a doentes. Eu morava na fazenda, e minha mãe sempre cuidava das pessoas doentes. Naquele tempo de sífilis, naquele tempo de outras doenças assim, ela sempre fazia isso na fazenda, ela mesma dava as injeções, meu pai também dava, e o médico sempre ia lá.

Em conversas com os médicos, o meu interesse em fazer o curso de enfermagem foi manifestado, e como a família que era dona da fazenda morava no Rio de Janeiro e conhecia a Escola Anna Nery, ${ }^{19}$ então o dr. João Burlamarque encarregou-se de verificar o que teria que ser feito para o meu ingresso na Escola Anna Nery, e para ela eu vim, com uma carta de indicação desse médico e outra do dr. Nelson Benchimol. ${ }^{20}$

Bem, corria o ano de 1940, e houve algumas restrições familiares aos meus projetos; meu irmão mais velho, que fazia a Escola de Polícia e era bacharel em direito, deixou claro as dificuldades e o conceito não muito bom que era atribuído às enfermeiras. Disse que era uma profissão não muito apreciada, pois as enfermeiras não tinham uma classificação social muito boa, e que achava estranho que eu a quisesse escolher. Então, queriam que eu fosse fazer o curso normal, que era o mais indicado, nas cidades da vizinhança. Eu teria que sair da minha cidade de qualquer maneira, pois lá ainda não havia Escola Normal. Mas firmei a minha decisão e, na metade do ano, eu fui para o Rio de 
Janeiro acompanhada de uma das senhoras, parente de um dos médicos que costumava ir à fazenda. ${ }^{21}$

Nós passamos por São Paulo e depois fomos para o Rio. De noite, eu tomei um trem, passamos por São José do Rio Pardo e vim com ela para São Paulo, que eu não conhecia. Hospedei-me em São Paulo, onde à noitinha dei uma volta e vi aquela garoa, aquela escuridão, tudo muito interessante. Passei a noite lendo e no dia seguinte seguimos de trem para o Rio de Janeiro. Eu me matriculei na Escola Anna Nery e fiz o curso de enfermagem de 1941 a 1943, sempre mantendo um relacionamento muito estreito com a família dona da fazenda que meu pai administrava.

Eu era uma aluna muito disciplinada, ativa, dinâmica e rápida em aprender e realizar coisas; durante o último ano fiz o curso de administração dado pelo grupo do Departamento de Administração de Saúde Pública (Dasp) do Ministério da Saúde. ${ }^{22} \mathrm{O}$ curso era dado por um pessoal de nível muito alto; então, a gente já saía do curso com uma noção de administração propriamente dita.

Durante o curso, por ser muito religiosa, tornei-me a coroinha do padre que rezava missa na capela da escola, e em nossa formatura eu respondi em latim à missa que foi rezada por dom Helder Câmara. ${ }^{23}$ Tornei-me amiga da diretora da escola, dona Laís Neto dos Reys, e ela recomendou-me que procurasse a madre Domineuc, diretora do Hospital São Paulo, quando soube que eu viria para São Paulo para trabalhar. Apesar de ter procurado a madre, não me animei em trabalhar com ela e seu staff e fui procurar o Hospital das Clínicas (HC) que, naquela época, em 1943, não estava pronto ainda. Eu tinha ouvido falar no Hospital das Clínicas e fui procurar emprego com a dona Hilda Kirsch, que era de Santa Catarina e tinha cursado a Escola Anna Nery. Dona Hilda era diretora convidada, participando do planejamento da Escola de Enfermagem da USP e do Serviço de Enfermagem do HC.

A Escola de Enfermagem da USP estava estruturada e o seu curso começando, e eu fiquei como professora na parte de técnicas na disciplina fundamentos de enfermagem, com a dona Zélia Carvalho. ${ }^{24} \mathrm{Eu}$ dava aulas de técnicas de bandagem e, como professora contratada pela escola, participava das atividades do hospital. Quem dirigia a área de enfermagem propriamente dita era a dona Edith de Magalhães Fraenkel, que tinha uma sala de reuniões no hospital, onde eram realizadas demonstrações sobre como seria o curso de enfermagem, técnicas e suas funções. Nessas reuniões no hospital, a estrutura administrativa básica do hospital (superintendente, assistente administrativo e assistente médico) estava presente, assistindo às demonstrações. O planejamento do hospital estava sendo feito paralelamente à sua construção: número de leitos, tipos de doentes, tipo de assistência a ser dada, e a cada reunião programada nós demonstrávamos uma técnica. Por exemplo, eu demonstrei a técnica de preparação do leito e a de banho no leito. Então, fazia uma cama, mostrava um banho do doente na cama sem 
molhar a cama, lavava a cabeça do doente na cama e fazia as técnicas, o que causava muita surpresa no pessoal.

O superintendente na época era o dr. Enéas de Carvalho Aguiar, que tinha parentesco com o governador Fernando Costa. Assim, de noite ele ia para o palácio e comentava os progressos, as demonstrações feitas pelas enfermeiras, que já tinha visto como era dado banho no doente etc. Isso era novidade em São Paulo: uma técnica que a Escola de Enfermagem empregava para ensinar as futuras enfermeiras e que o hospital estava se preparando para executar. Com o adoecimento da esposa do governador, eu fui prestar assistência de enfermagem a ela no palácio, e isso deu-me um certo trânsito por lá. ${ }^{25}$ As técnicas novas introduzidas, todo o planejamento davam um status, prestígio à enfermagem.

O dr. Odair Pacheco Pedroso e a dra. Lourdes Freitas, que fizeram cursos de administração hospitalar nos Estados Unidos, também nos davam prestígio. Tudo isso criava um bom relacionamento e dava destaque ao nosso trabalho. Quando o hospital recebeu o primeiro doente, aí bateu aquela vontade de ficar com ele, porque era isso o que eu fazia antes e que eu gostava de fazer. Eu quis passar da escola para o hospital, o que foi viabilizado pelo dr. Enéas, colocando-me subordinada à dona Edith e à dona Hilda, como enfermeira do seu staff. Comecei como enfermeira no pronto-socorro, onde assisti como instrumentadora à primeira cirurgia lá realizada.

Nesta época começou o primeiro internato no HC, com médicos que vinham nos questionar para saber o quanto éramos realmente capazes. Eles perguntavam assim: "Vocês sabem tomar a pressão? Vocês sabem fazer isso aqui?" Quer dizer, questionavam o que nós sabíamos. É lógico que sabíamos! Se estávamos lá, era para saber e para fazer. Éramos sempre colocadas à prova, mas trabalhávamos bem. Pessoas, médicos formidáveis, trabalhavam nessa época no HC, como o professor Alípio Correia Neto, que foi reitor da USP, o professor Zerbini, o professor Nicolau Moraes de Barros, o professor Celestino Bourroul e outros.

Nós residíamos no hospital, no sexto andar, e dávamos assistência a emergências noturnas, quando éramos solicitadas. Era um tipo de assistência integral ao hospital. A diretora de enfermagem tinha uma sala no quinto andar, com sua secretaria. A superintendência era no quinto andar, as reuniões eram no quinto andar, onde a enfermagem já tinha se situado, na ala central, e onde fiquei, muito tempo depois, como diretora de enfermagem. A secretária da enfermagem era uma pessoa de peso, de responsabilidade e que trabalhava muito, e eu ainda era jovem por lá. Eu era a última da fila na lista de assinatura do ponto, porque era a mais jovem. Contou-me esta secretária, depois de muito tempo de decorrido o fato, que, um dia, eu disse: "Olha, dona ..., eu estou aqui embaixo, mas o meu lugar é aqui em cima." Então, eu já era meio arrojada, já querendo mandar, e realmente eu fui fazendo uma carreira. 
Eu trabalhei por um período na clínica médica e também na clínica urológica. Chegava cedo na enfermaria, via todos os doentes, as ordens, checava se as determinações haviam sido cumpridas e dividia o serviço pelos funcionários; acompanhava a visita médica e dava assistência de enfermagem no que e como fosse necessário. A enfermeira avaliava o cuidado do paciente e, então, sabia a medicação que tinha que dar, o que ele tinha feito. Se você fechasse os olhos, sabia quantos doentes você tinha, o nome do paciente, quem estava cuidando dele, qual era a doença dele, qual a medicação que ele tinha que tomar, qual já tinha tomado, o que ele tinha que fazer no dia seguinte, porque estávamos vivenciando aqueles cinqüenta pacientes naquela unidade. ${ }^{26} \mathrm{Eu}$ conhecia todos os pacientes, suas doenças, suas medicações, seu programa de tratamento.

Em nosso staff, trabalhávamos com atendentes e auxiliares de enfermagem, que eram treinados para exercer as suas funções, mas tínhamos sempre um número inferior ao realmente necessário, portanto, nos desdobrávamos para dar uma assistência boa aos pacientes. No início da formação do hospital, trabalhavam conosco os antigos 'enfermeiros' práticos licenciados do Estado. ${ }^{27}$ Gente séria, bons profissionais que deram algum trabalho até aceitarem a nossa autoridade de enfermeira, mesmo porque em algumas áreas só existiam eles como profissionais, e nos os apoiávamos em seu trabalho. E nos apoiávamos nestes antigos enfermeiros práticos licenciados porque tínhamos poucos enfermeiros. Nunca tivemos muitos enfermeiros e precisávamos dividir o serviço, e como eles eram funcionários que queriam ser prestigiados naquela atividade, que já praticavam antes de chegarmos a São Paulo, tínhamos que saber tratá-los com a deferência adequada, mesmo porque, entre eles, havia profissionais muito sérios. O entendimento com esses profissionais possibilitou-nos a aproximação com o sindicato. Então, eu comecei a participar das reuniões, dos eventos, e criei um bom ambiente, adquiri respeito e deferência por parte do pessoal do Sindicato de Enfermeiros e Empregados de Hospitais e Casas de Saúde. ${ }^{28}$ Você contava para trabalhar com o atendente de enfermagem, que nós selecionávamos, e, após serem submetidos ao exame de saúde, passavam por treinamento, e com o auxiliar de enfermagem, que revisava as técnicas e depois era alocado para a área onde ele era competente.

As enfermeiras também eram treinadas, quando chegavam, para conhecer o hospital. Reviam algumas técnicas diferentes e aparelhos diferentes. Nós sempre atribuímos às enfermeiras as técnicas mais avançadas. Já a enfermeira chefe tinha outras atividades, mais administrativas. O pessoal falava: "Mas só fica com o caderno debaixo do braço?" Era aquele conceito antigo de achar que a enfermeira não via o doente. Ela não deixava de ver o doente. Ela o via através de outras atividades. Não é todo mundo que enxerga isso. O fato de ela estar com uma agenda na mão não quer dizer que ela não está fazendo alguma coisa para o doente. Ela estava fazendo, pois trabalhávamos no 
sentido de atender o doente da melhor maneira possível, sendo vistos como pessoas que tinham que receber um tratamento integral. ${ }^{29}$

O hospital foi crescendo, e eu participava da montagem inicial de cada unidade; eu preparava leitos, instalações, recebia o primeiro doente e depois uma colega assumia. Quando a ortopedia saiu e foi para o prédio novo, também nós fomos para lá, pois eu sempre estava presente nas instalações. E na psiquiatria também. Eu me lembro que, quando a clínica psiquiátrica começou a funcionar, em 1954, nós havíamos acabado de chegar dos Estados Unidos. Passamos uma temporada daquele ano no Columbia University Teacher's College e estávamos bem atualizadas. Questionávamos muito o professor da clínica, de quem não me recordo o nome, porque a idéia de psiquiatria dele era o doente ficar amarrado, dentro do quarto, daquele jeito antigo. Eu então questionava, porque havia acabado de chegar dos Estados Unidos, onde tinha adquirido conhecimentos recentes de psicologia sobre o tratamento do paciente, e enfrentava dificuldades quando questionava sobre a acomodação do paciente, sua separação dos demais etc.

Também me lembro de ter questionado tanto algumas coisas que o professor da clínica obstétrica queria fazer, e um dia, comentando o fato na reunião do conselho deliberativo, ele disse que queria dar um piparote na minha touca, porque eu era muito imponente. Então, às vezes, essas pessoas se incomodavam, não digo que com a arrogância, mas com as colocações que eu fazia. Eu não acho que tenha sido uma "criadora de casos", mas reconheço que sempre aproveitei as oportunidades que tive para manifestar o meu ponto de vista. ${ }^{30}$

Pode-se dizer que eu vivia para o hospital. Mesmo quando não era mais residente, eu não tinha hora para sair de lá; não tinha, como hoje é comum para a maioria das enfermeiras, um segundo emprego, bem como ninguém tinha naquela época. Minha família sempre me apoiou e entendeu o que eu estava fazendo, via que eu gostava e estava feliz e, então, não me faziam restrições. Era uma família fantástica. Da mesma maneira como eu ficava no hospital o dia inteiro quando morava lá, mesmo não morando mais ficava o dia inteiro também. Nunca tive problema de ir correndo para casa ou para ir trabalhar. Eu trabalhava no hospital, era a primeira a chegar e a última a sair. Sabia de tudo, ninguém me enganava em nada. Eu mandava fazer uma coisa mas quando elas iam fazer, às vezes, eu já tinha feito, quando elas iam conferir, eu já tinha conferido. Então, eu sempre fui muito diligente nas coisas e participei muito, nesse período de trabalho no hospital, da formação do nosso pessoal.

Com a saída de dona Hilda por motivos de saúde, eu, que estava como supervisora, acabei ficando como diretora de enfermagem. Apesar de jovem, recebi todo o apoio das colegas: era uma turma muito boa, nos relacionávamos bem, era como se fosse uma grande família. Tínhamos uma convivência muito boa, um grupo com um interesse comum. Nós tínhamos enfermeiras muito boas no hospital e adquirimos 
um conceito muito bom, uma valorização. As enfermeiras ficavam muito tempo no emprego porque não havia tantos hospitais em São Paulo, e na iniciativa privada quem fazia o serviço era a atendente, que era chamada de enfermeira. Então, não havia um turnover muito alto. ${ }^{31}$

de cinco ou seis enfermeiras no qual eu estava incluída foi enviado aos Estados Unidos, com eu já disse, para fazer um curso de um ano no Columbia University Teacher's College, com a ajuda da Kellogg Foundation. Eu fiz um curso na área de administração e, ao voltar, fui a tradutora do curso de team work (trabalho em equipe), que miss Lambertsen ministrou aqui. As noções aprendidas no curso feito nos Estados Unidos foram de grande valia em meu dia a dia, fazendo-me, por vezes, questionar posturas médicas. Às vezes tínhamos problemas com um ou outro professor pelo nosso questionamento, mas acabávamos chegando a um acordo e, com isso, a enfermagem era respeitada e considerada.

Quando eu era diretora, logo no início, houve uma mudança no regulamento, e a Escola de Enfermagem e o hospital foram separados; a escola continuava a ter estagiários lá dentro, mas a diretora de enfermagem se reportava agora ao diretor do hospital, e não mais à diretora da escola; a cooperação continuava, mas a subordinação deixava de existir. Naquele tempo, algumas enfermeiras que estavam no corpo docente da escola, como a dona Maria Rosa Pinheiro $^{32}$ e as irmãs Verderese, ${ }^{33}$ traziam muita contribuição para a enfermagem. Elas faziam estágio de cirurgia nas várias clínicas e sofriam demais, porque o hospital sempre teve pouca gente, e elas trabalhavam demais, entrando noite adentro, fazendo as coisas com toda segurança, com todo detalhe, com todo pormenor que aprenderam nos Estados Unidos e no Canadá. Eu acho que a enfermagem do Hospital das Clínicas teve um privilégio muito grande ao poder contar com pessoas daquele gabarito no seu início.

A enfermagem foi a primeira a ter estrutura definida, hierarquizada, a estrutura de serviço com atribuições delimitadas; os outros serviços existiam — médico, nutrição e dietética, serviço social —, mas não tão estruturados, e, então, a enfermagem tinha naturalmente uma posição de liderança. A enfermeira sempre se posicionou e, naquele tempo, já se pensava na estrutura do serviço, na atribuição da enfermagem, da chefe, supervisora etc. ${ }^{34} \mathrm{O}$ corpo clínico do hospital, depois de muito tempo, resolveu abrir os olhos e se perguntou: "Por que a enfermagem tem uma estrutura e nós não temos? Por que tinha na enfermagem uma pessoa que tomava conta da enfermaria e não tinha um médico que também o fizesse?" Eles comentavam isso nas suas reuniões, e nós ficávamos sabendo.

O hospital, pelo trabalho que realizava, pioneiro em muitos campos, sempre recebeu estagiários de outras regiões do Brasil, de Norte a Sul, além de receber pessoas de países da América do Sul, como Uruguai, Argentina, Chile, que passavam também pelo serviço de enfermagem. 
Eram sempre bem recebidas e, não raramente, nos mandavam correspondências após terem voltado para seus locais de origem. Também recebíamos sempre estagiários de administração hospitalar, que, no começo dos anos 1950, também passavam conosco. A enfermagem do HC influenciou muito a administração hospitalar, porque, na hora em que eles vinham fazer estágio conosco, acompanhavam o atendimento do doente, faziam o horário da enfermeira, ficavam na enfermaria, viam bem de perto as necessidades hospitalares para que o doente fosse atendido, viam que era diferente de fazer um cursinho e ir embora.

A enfermagem sempre participou de atividades, reuniões importantes, eventos, inaugurações que ocorriam no hospital ou ligados ao trabalho desenvolvido pelas várias equipes; participávamos também de congressos, encontros e jornadas. A Associação Brasileira de Enfermagem (ABEn) esteve ligada à minha vida durante muitos anos. Eu participei dela desde o começo, da compra da sede em Brasília até a colocação da mobília, tarefa na qual contei com a ajuda e o bom gosto de uma de minhas irmãs. Eu trabalhava para a ABEn nas cobranças, nos eventos, nos congressos, e todas as enfermeiras, em meu tempo de diretoria, eram associadas à ABEn. Eu me lembro que nenhuma enfermeira do hospital, no meu tempo, deixava de ser sócia da ABEn. Por bem ou por mal. Se ela tinha dinheiro, pagava. Se ela não tinha, eu adiantava, eu emprestava, eu pagava, mas tinha que ser sócia. ${ }^{35}$

Tivemos líderes formidáveis na ABEn, de vários lugares do Brasil, que incentivavam, promoviam a enfermagem. Íamos a congressos, eventos, jornadas, sempre na vanguarda e tentando trazer o melhor para a classe - era um grupo menor, de elite, coeso, esforçado e com interesses comuns. Depois a enfermagem foi ficando mais popular, mais distribuída, com faculdades que a gente não conhece direito e pessoal de outros níveis sociais. ${ }^{36}$ Nos nossos congressos, sempre o HC se levantava para falar, para ter uma mensagem, para apresentar um trabalho. Ele não passava despercebido. Sua presença era notável. Nossa equipe, nossa atuação eram objeto de atenção. Tínhamos relevância no país, aparecíamos nos congressos e éramos procuradas. Graças à ABEn, eu pude ter contato com pessoas do Brasil inteiro. Era enriquecedor, além de divertido e gostoso. É claro que tínhamos problemas, dificuldades, mas conseguíamos resolvê-los.

A enfermagem, durante muitos anos, foi importante no hospital. Éramos respeitadas, a nossa assistência era considerada boa, apesar de todas as dificuldades que enfrentávamos. A enfermagem sempre esteve par e passo com as coisas melhores, com a superintendência, em posição de destaque. O pessoal dizia que quem mandava no hospital era a enfermagem, mas, na verdade, sempre estivemos juntos, tendo os diretores do hospital se apoiado no trabalho, na qualidade, no prestígio, na eficiência e na honestidade da enfermagem, que era a base de tudo.

Na minha época de diretora, o dia começava cedo. Antes das sete horas eu já estava no hospital, uniformizada. Sempre usamos o uniforme 
— inteiro e impecável, de acordo com o regulamento, de acordo com a tradição, o que era aprovado pelas enfermeiras do serviço de enfermagem. ${ }^{37}$ Antes de receber o plantão, eu já tinha dado uma volta pelo hospital, recebia o plantão geral em minha sala, ao mesmo tempo que as supervisoras e assistentes. Depois ia visitar todas as unidades do hospital, andar por andar. Eu conhecia todos os funcionários por nome, os chefes, o pessoal de outros serviços, médicos: como eu ajudei a montar cada unidade, conhecia todos os professores e, com a residência médica iniciando, eu os conhecia também. Na parte da tarde, a minha sala tornava-se um ponto de encontro onde os médicos costumavam ir para conversar, fazer perguntas, trocar idéias.

A enfermagem também saía muito para dar aulas, participar de reuniões e acontecimentos que envolviam a comunidade. É claro que nem sempre fomos vitoriosas. Tivemos que ultrapassar dificuldades e houve situações em que não fomos atendidas, ocasiões em que chorei e fiquei triste; mas nunca esmoreci e creio que a nossa luta foi a base para muitas conquistas, para o respeito que a enfermagem muitas vezes conquistou. Naquela época tivemos que acertar horários, equipes para cada plantão durante o correr do dia e, como os outros serviços não eram tão estruturados, nós tínhamos que suprir. Por exemplo, a roupa necessária, as dietas, os medicamentos, que eram funções básicas de outros serviços, mas que, se não fôssemos providenciar, o paciente ficaria sem o completo e adequado atendimento. Este é o lado administrativo da enfermagem, tão importante quanto a assistência direta ao paciente, mas que era visto como menos importante, ou mais fácil, o que é um grande erro. A enfermagem de minha época era um grupo coeso, que procurava se ajudar. Chegávamos até a financiar a faculdade de enfermagem para as auxiliares (de enfermagem) que eram boas profissionais, que se destacavam; havia um espírito de corpo que parece não existir hoje.

$\mathrm{Na}$ época do governo Jânio Quadros, exerci interinamente a diretoria da Escola de Enfermagem, porque ele criou muitas dificuldades, afastou diretores e diretoras; eu fiquei na escola para ajudar a segurar a situação e recebia 'bilhetes' do Jânio, naquele seu estilo pessoal de administrar. Aceitei esse encargo para evitar que professoras de outra escola fizessem a substituição da diretora, até que fosse nomeada uma das professoras da própria EEUSP. ${ }^{38}$

Durante o governo Carvalho Pinto, ajudei a estruturar o Hospital Infantil Darcy Vargas, no Morumbi. Era diretora de enfermagem do HC e trabalhava como assistente do diretor do hospital infantil. Era respeitada, conhecida, o governador ficava esperando a minha chegada para assinar, decidir e resolver assuntos relativos ao hospital.

Em 1968 e 1969, a época inicial dos transplantes, a enfermagem trabalhou lado a lado com a equipe do dr. Zerbini e seus assistentes. Acompanhamos todo o trabalho experimental realizado na faculdade, demos todo o suporte, o apoio. Todo o procedimento do transplante 
foi pensado em conjunto: como a equipe seria dividida, as salas cirúrgicas, todo o intra e o pós-operatório, as técnicas mais adequadas, o isolamento do paciente etc. No dia da realização do transplante, eu fiquei na sala do receptor, e o professor Zerbini na de remoção do coração. Acompanhamos o ato de retirada e transposição do coração para o doador e vimos o coração batendo, tirando o sangue, tirando o coração, levando o coração e este batendo no receptor. O professor Zerbini tinha um grande apreço pela enfermagem, e nós participamos de todos os eventos nacionais e mundiais, como a ida à Cidade do Cabo, para a homenagem prestada pelo dr. Barnard ao dr. Zerbini e equipe.

Quando a equipe de enfermagem da Santa Casa de Santos teve problemas administrativos, nós ajudamos, garantindo a assistência de enfermagem até que estivesse tudo resolvido. Nós sempre recebemos apoio na parte administrativa, com o dr. Odair Pedroso e outros que nos prestigiaram, incentivaram nosso crescimento, o estudo e a constante participação. A enfermagem festejou muito isso e eu achei que estava satisfeita e plenamente realizada e que tinha que deixar a oportunidade para outras colegas minhas que estavam ali. Foi quando eu me aposentei em 1969.

Depois de me aposentar, continuei ligada ainda ao hospital, desenvolvendo um trabalho de assessoria: participava de reuniões, comissões, e fiz a primeira proposta de criação da Comissão de Infecção. Eu fiquei no planejamento do Instituto do Coração e viajei, junto com uma equipe muito boa, para os Estados Unidos, a Europa, conhecendo vários hospitais para que pudéssemos ter o melhor na época em arquitetura, estrutura, pessoal e serviços. O desenho do Instituto do Coração foi feito na minha mesa de diretora do quinto andar, ${ }^{39}$ e acompanhei todo o seu estudo. Nas reuniões eu estava junto, a agenda era feita comigo, as datas eram marcadas comigo, a discussão do prédio inteiro era feita comigo.

De 1980 a 1993, trabalhei na assessoria do Hospital das Clínicas, ocasião em que requeri o meu desligamento do serviço público. Resumindo, eu acho que fui uma pessoa que entrou numa área de que gostava, se adaptou, que viveu, que teve experiência, que soube passar para outras pessoas. Eu acho que vivi a enfermagem de uma maneira muito plena, muito agradável. Supriu minhas necessidades de realização pessoal em muito, embora eu não tivesse casado (poderia ter tido uma família), mas acho que tive uma família maior e, mesmo quando fora da enfermagem, acho que também a dignifiquei. Acredito que dei à enfermagem aquilo que devia ter dado mesmo e acho que, se fosse hoje e tivesse que começar outra vez, talvez eu fizesse enfermagem novamente, porque cuidei de doente, segurei em muita mão de doente que ia morrer, ajudei muito doente a melhorar e vivi a vida do doente também. Então, eu acredito que fui uma pessoa feliz na enfermagem e feliz para a enfermagem, porque fiz muita coisa de que gostei. 
CLARICE DELLA TORRE FERRARINI: DEPOIMENTO DE UMA PIONEIRA

\section{NOTAS}

${ }^{1}$ A Escola de Enfermagem Anna Nery, a primeira escola brasileira concebida no modelo anglo-americano que prosperou, foi criada em 1922 e regulamentada em 1923, no Rio de Janeiro, e se chamou inicialmente Escola de Enfermeiras do Departamento Nacional de Saúde Pública. Formou sua primeira turma em 1925 e se integrou plenamente à Universidade do Brasil, atual Universidade Federal do Rio de Janeiro (UFRJ), como instituição de ensino superior, em 1946 (Carvalho, 1976).

${ }^{2}$ Laís Neto dos Reys foi a primeira diretora da EEAN formada na própria escola. Exerceu esse cargo de 1938 a 1950, quando exerceu grande influência no cenário nacional de saúde, ensino e enfermagem. Como diretora da escola padrão, era responsável por coordenar as atividades de reconhecimento das demais escolas de enfermagem do país. A Escola de Enfermagem Anna Nery foi designada escola padrão pelo decreto 20109/31, que estabelecia que as escolas que pretendessem formar enfermeiras deveriam se adequar ao padrão annaneriano.

${ }^{3}$ Madre Domineuc dirigia a Escola de Enfermeiras do Hospital São Paulo à época em que Clarice Ferrarini estudou na EEAN e iniciou suas atividades no HCFMUSP. Era muito próxima de Laís Neto dos Reys, que reconheceu a escola em 1942, um ano antes da formatura de Clarice Ferrarini na EEAN, e no mesmo ano em que a Escola de Enfermagem anexa à Faculdade de Medicina da Universidade de São Paulo, hoje Escola de Enfermagem da USP, iniciou suas atividades.

${ }^{4}$ O Hospital das Clínicas da Faculdade de Medicina da Universidade de São Paulo foi inaugurado em 1943, mas iniciou suas atividades em 1944, vindo a instalar a totalidade de suas unidades anos mais tarde.

${ }^{5}$ Atendendo à solicitação do interventor do estado de São Paulo, Hilda Krish foi indicada pelo Departamento Nacional de Saúde Pública para proceder à organização da enfermagem do Hospital das Clínicas de São Paulo e permaneceu nessa função até 1945. Foi presidente da Associação Brasileira de Enfermagem de 1938 a 1941.

${ }^{6}$ Edith de Magalhães Fraenkel era diretora do Serviço de Enfermagem do Departamento Nacional de Saúde Pública quando foi convidada a dirigir a Escola de Enfermagem da Universidade de São Paulo, fundada em 1942. Houve uma tentativa anterior de instalar um curso no modelo annaneriano, e Laís Neto dos Reys participou de estudos para avaliação dessa possibilidade, que não se concretizou à época.

${ }^{7}$ Dos anos 1920 aos anos 1960, as enfermeiras que se destacavam no curso ou em suas atividades profissionais eram enviadas aos países em que o modelo anglo-americano de enfermagem estivesse mais desenvolvido, como Estados Unidos e Canadá, por exemplo, para se prepararem para dirigir as escolas de enfermagem que viriam a ser abertas no Brasil e para dirigirem a enfermagem nos postos de destaque nos órgãos públicos de saúde. Maria Rosa de Souza Pinheiro, por exemplo, que foi por muitos anos diretora da EEUSP, seguiu esse caminho.

${ }^{8} \mathrm{O}$ "trabalho em equipe", como proposto por Lambertsen, foi um modelo de organização do trabalho da enfermagem experimentado entre os anos 1950 e 1960 na instituição citada, mas não pôde ser totalmente implantado, entre outras razões, pela insuficiência da distribuição quantitativa e qualitativa da força de trabalho em enfermagem à época.

${ }^{9}$ Em 1946 foi proposto o primeiro curso de administração hospitalar, por Theophilo de Almeida, que mais tarde se tornou diretor da Divisão de Organização Hospitalar do Ministério da Saúde. Realizado por 15 anos na Escola Nacional de Saúde Pública (ENSP), no Rio de Janeiro, foi secundado, nos anos 1960, pelo programa organizado por Odair Pacheco Pedroso, com o apoio da Kellogg Foundation, na Faculdade de Saúde Pública da Universidade de São Paulo. Outras iniciativas foram se sucedendo até que, em 1973, foi aprovado o primeiro currículo mínimo para a habilitação em administração hospitalar. Este era constituído de 'matérias básicas' de formação geral, 'matérias profissionais comuns' à formação do administrador e 'matérias profissionais específicas' de formação do administrador hospitalar, mais o estágio supervisionado em hospital, compondo a grade curricular de 2.700 horas a ser integralizada em no mínimo três e no máximo sete anos, em contraste com o curso de administração de empresas, cujo currículo mínimo estabelecia três mil horas, como consta da resolução 2/93 do Conselho Federal de Educação. A primeira faculdade de administração hospitalar do país instalou-se em 6 de dezembro de 1973, no Instituto Brasileiro de Desenvolvimento e de Pesquisas Hospitalares (IPH), tendo como sucessor o curso de administração hospitalar das Faculdades São Camilo, hoje Centro Universitário. Ver Cherubin et al. (1999).

${ }^{10}$ Essas unidades de trabalho eram uma novidade na época em que foram criadas, tendo sua inspiração no modelo americano de organização de hospitais.

${ }^{11}$ Esta publicação ainda hoje é referência nacional quando se estuda a construção de indicadores para a avaliação da assistência de enfermagem tanto hospitalares quanto ambulatoriais. Embora seu conteúdo possa ser questionado pelo avanço do conhecimento em enfermagem, sua formatação e a forma como a experiência foi conduzida permanecem atuais.

${ }^{12}$ Mais tarde essas definições foram integradas à famosa portaria 400, que disciplinou a construção de estabelecimentos de saúde. A despeito de sua substituição por portarias de outros números que reviam e atualizavam esses conceitos, ela ainda designa genericamente essas regulamentações. A última versão é de 2002

${ }^{13}$ A divisão da representação dos profissionais em órgãos com funções complementares mas natureza jurídica e atribuições diferenciadas foi uma manobra do governo militar para evitar a organização de resistências. Na enfermagem, ao Conselho Federal e aos conselhos regionais, fundados em 1973, coube o encargo de fiscalizar o exercício profissional; à Associação Brasileira de Enfermagem (que antes teve o nome de Associação Nacional de Enfermeiras Diplomadas e depois de Associação Brasileira de Enfermeiras Diplomadas e, finalmente, o nome atual e a sigla ABEn) e suas seções estaduais, a entidade mais 
tradicional, coube a função de representatividade social e política e as ações para o desenvolvimento da profissão. Finalmente, aos sindicatos, constituídos a partir da década seguinte, ficaram reservadas as ações relacionadas à conquista e manutenção de condições de trabalho.

${ }^{14}$ A revista, fundada em 1931, que inicialmente se chamava Annaes da Enfermagem, deixou de ser publicada no período da guerra, de 1942 a 1945, e enfrentou diversas dificuldades para manter sua periodicidade depois disso. A aproximação entre as enfermeiras dirigentes da associação e os fabricantes de produtos médico-hospitalares facilitou a obtenção de patrocínio por um determinado período. Nas edições dos anos 1960 a 1970 é possível contemplar anúncios desses produtos nas páginas da revista. Depois, com a busca da preservação do caráter científico e a indexação em bases de dados internacionais, abandonou-se essa prática.

${ }^{15}$ O curso de formação de técnicos de enfermagem, embora já discutido no âmbito da ABEn há mais tempo, desde 1952, só foi implementado experimentalmente em 1965 e oficialmente reconhecido pelo parecer 171/66 da Câmara de Ensino Primário e Médio do Conselho Federal de Educação, com o caráter de curso profissionalizante no nível de segundo grau, em caráter de terminalidade, embora habilitando o concluinte ao vestibular para o nível superior.

${ }^{16}$ A Associação Brasileira de Enfermagem, como hoje, era o organismo que representava os interesses políticos da enfermagem brasileira. Ser presidente da associação era uma das posições de maior destaque que uma enfermeira poderia almejar na época em que Clarice Ferrarini exerceu o seu mandato. O posto era ocupado por diretoras de escolas de enfermagem ou de órgãos de saúde que exercessem grande influência no cenário nacional. Seu trabalho era articular as diversas seções em torno dos programas e idéias defendidos pelas enfermeiras e relacionar-se com outras corporações, dentro e fora da enfermagem e principalmente com todas as instâncias de poder político que circundassem as áreas de saúde e educação, dentro e fora do país. Foram conquistas da ABEn no período que circunda a formação e início da atuação profissional de Clarice Ferrarini: a classificação da enfermeira entre as profissões liberais, no quadro de atividades e profissões do Ministério do Trabalho, Indústria e Comércio, em 1940; a criação do dia do enfermeiro por decreto presidencial de Getúlio Vargas, em 1938; a realização da primeira Semana de Enfermagem em 1940; a representação na Federação Pan-Americana de Enfermagem, em 1942, no Conselho Internacional de Enfermagem em 1929; a realização do 1² Congresso Nacional de Enfermagem em 1947 e do $10^{\circ}$ Congresso Internacional de Enfermagem ocorrido em 1953, entre outros fatos marcantes.

${ }^{17}$ Esse concurso era objeto de muita disputa. No ano em que Clarice Ferrarini foi a escolhida, concorreram com ela mais nove candidatas: Josephina de Mello, pelo Amazonas, Maria do Rosário S. Nóbrega e irmã Jorgina da Silva, por Pernambuco, Delzuite de Souza Cordeiro, pelo Distrito Federal, Celina Viegas, por Minas Gerais, Maria Silvia D’Oliveira Couto, por Sergipe, Justina Lacy Regeanini e irmã Margarida Kloppenburg, pelo estado do Rio Grande do Sul. Por São Paulo, Guanabara e estado do Rio de Janeiro concorreu a ganhadora e Wanda de Aguiar Horta, que seria reconhecida mais tarde como a primeira teórica da enfermagem brasileira e a primeira enfermeira a ocupar o posto de professor titular numa universidade brasileira (EEUSP). Manifestação sobre a premiação pode ser encontrada em Neme (1969).

${ }^{18}$ Euclides da Cunha era fiscal de obras do governo de São Paulo e supervisionou a construção de uma ponte metálica na cidade, que ruiu logo após a inauguração. Voltou então à cidade e nela morou até que, sob suas ordens, a ponte fosse reconstruída. No tempo em que lá esteve, escreveu boa parte de Os sertões.

${ }^{19}$ A Escola de Enfermagem Anna Nery, inicialmente denominada Escola de Enfermeiras do Departamento Nacional de Saúde Pública, foi criada como resultado dos trabalhos da Missão Parsons - a vinda de uma comissão de enfermeiras americanas ao Brasil em 1921. Entre outras atividades, a comissão foi responsável pela implantação, com sucesso, do modelo anglo-americano de enfermagem no Brasil. Passou a ter o nome atual, com a promulgação do decreto 20109/31, em homenagem à heroína da guerra do Paraguai, Anna Justina Ferreira Nery, que cuidou dos soldados feridos.

${ }^{20}$ A seleção para ingresso na escola requeria o cumprimento de vários quesitos, entre os quais a indicação de duas pessoas idôneas que atestassem os atributos de moralidade da candidata. Na ficha de admissão de Clarice Ferrarini, é possível identificar esses dois nomes.

${ }^{21} \mathrm{Na}$ época citada, as mulheres de classe média baixa eram criadas para o matrimônio e a maternidade, admitindo-se como profissionalização a formação para o ensino em escolas primárias, a qualificação para o exercício do ofício de secretária e, com todos os óbices representados pela má fama de que desfrutavam as trabalhadoras dos hospitais, a preparação para ser enfermeira. Essas mulheres não se deslocavam sozinhas para estudar em outras cidades. Quando o faziam, moravam preferencialmente nas escolas ou mais raramente com parentes.

${ }^{22}$ A instituição da exigência de diploma de enfermeiro para ingresso nos cargos públicos por concurso foi uma das grandes lutas encaminhadas pela ABEn. Como o concurso previa a argüição sobre matérias de administração pública, a Escola de Enfermagem Anna Nery ofereceu um curso em suas dependências para as alunas do último ano, a fim de prepará-las para obter a melhor classificação no concurso e assim conquistarem os cargos.

${ }^{23}$ A moral cristã impregnava a formação da enfermeira annaneriana e a aproximação dos rituais católicos foi muito valorizada durante a gestão de Laís Neto dos Reys, praticante fervorosa.

${ }^{24}$ Zélia Carvalho também era ex-aluna da EEAN. 
${ }^{25}$ A prática de requisitar alunos e professores de escolas de enfermagem para prestar assistência às autoridades e seus familiares era bastante comum na época. Na formatura de Clarice Ferrarini, foram paraninfo e madrinha das iniciantes, respectivamente, o interventor do estado do Rio de Janeiro e sua mulher, a filha de Getúlio Vargas, que recebera assistência de enfermagem de profissionais e alunas da escola durante uma enfermidade. Essa convivência também era estimulada por meio de convites a essas autoridades para proferirem palestras para alunas e professoras na escola e nela participarem de eventos comemorativos e/ou sociais, o que garantia proximidade das líderes e suas futuras sucessoras do poder instituído.

${ }^{26}$ O quantitativo de enfermeiras na instituição em foco era pequeno naquela época, e os postos de trabalho, parcamente distribuídos. Assim, as atividades administrativas ficavam a cargo freqüentemente da única enfermeira que havia no quadro da unidade, que pouco prestava assistência direta, ocupando-se em supervisionar a equipe de enfermagem e em atender às demandas dos outros profissionais, principalmente dos médicos e estudantes de medicina, já que se tratava de um hospitalescola.

${ }^{27}$ A disputa pelo uso da denominação de 'enfermeiro' foi uma constante para as enfermeiras que se formaram nos vinte primeiros anos de existência do modelo anglo-americano de enfermagem no Brasil, que finalmente saíram vitoriosas com a promulgação da lei 775 de 1949. Há poucas indicações e estudos realizados sobre a formação de outros profissionais em outros modelos de preparação de profissionais de enfermagem, mas sabe-se que, embora o modelo annaneriano servisse aos interesses do poder instituído, um contingente nada desprezível de leigos treinados e profissionais formados para este fim, que se estendia das irmãs da caridade aos membros das armas, ficou muito descontente com esses encaminhamentos, empenhando-se em vários movimentos de resistência.

${ }^{28}$ Por muito tempo, em São Paulo, a representação profissional das demais funções de atendentes da enfermagem que não o enfermeiro ficou por conta desse sindicato. Apenas nos anos 1990, os auxiliares e técnicos de enfermagem constituíram um sindicato próprio.

${ }^{29}$ A divisão intelectual e manual do trabalho não era específica da área de enfermagem, no trabalho em saúde. Apenas era mais evidente nessa corporação, porque havia e ainda há profissionais com preparo e responsabilidades diferentes e bem demarcadas. Um pouco mais tarde, como correlato dessa situação, na instituição citada, começaram a surgir os auxiliares médicos, de serviço social, de farmácia, e assim por diante.

${ }^{30}$ Os conflitos entre a equipe médica e as enfermeiras parecem fazer parte da natureza do trabalho de ambos. A novidade, no caso apresentado pela narradora, está no fato de a enfermeira julgar seu desempenho no uso do conhecimento e a reação do contendor a essa variável, em lugar de valorizar dimensões afetivas desse relacionamento.

${ }^{31}$ A dedicação a uma única instituição e a construção de uma carreira profissional nessa mesma organização era um valor da época, em que não era necessário manter dois ou mais empregos para atender às expectativas de ascensão social e desenvolvimento profissional. Daí a constatação de um índice de substituição de mão-de-obra tão baixo naquele período. Além disso, a maior parte dos postos de trabalho para enfermeiros eram públicos, e a acumulação era vedada, como até recentemente.

32 Maria Rosa de Souza Pinheiro foi professora e depois diretora da Escola de Enfermagem da USP por muitos anos. Sucedeu Edith de Magalhães Fraenkel, mas, antes que assumisse o cargo, em 1955, este foi interinamente ocupado por Clarice Ferrarini, a mando do governador Jânio da Silva Quadros. A saída de Edith de Magalhães Fraenkel parece ter sido traumática e não tem seus motivos documentados, mas a nomeação de Clarice Ferrarini tampouco satisfez aos corpos discente e docente. A vinda de Maria Rosa de Souza Pinheiro apaziguou os ânimos e deu início a um período de muitas realizações e conquistas para a EEUSP e para a enfermagem brasileira.

33 Olga e Maria de Lourdes Verderese eram irmãs, formadas na Escola de Enfermagem Anna Nery, que lecionaram na EEUSP e tiveram projeção nos trabalhos da Associação Brasileira de Enfermagem.

${ }^{34}$ Durante a formação, as estudantes de enfermagem eram supervisionadas pelas "seniores", alunas mais adiantadas, além da enfermeira da unidade de atendimento e da enfermeira docente. As dirigentes dos órgãos de enfermagem dos serviços de saúde tinham suas assistentes, assim como a diretora da escola. Esses personagens freqüentemente coabitavam o espaço denominado internato, onde essas relações de poder continuavam a ser reproduzidas e faziam parte do funcionamento da residência. Por essa aproximação entre as atividades de ensino e de assistência/administração, pode-se explicar a natural transposição do modelo vivenciado no ambiente de formação para o ambiente de trabalho e o pioneirismo da enfermagem na estruturação das linhas de autoridade no ambiente hospitalar.

35 Ao contrário do que acontece com os sindicatos e os conselhos Federal e regionais de enfermagem, a Associação Brasileira de Enfermagem sempre filiou associados por meio de adesão voluntária. Havia, no entanto, uma campanha de convencimento que era desenvolvida pelas líderes da profissão, representadas pelas docentes e dirigentes de escolas e dirigentes de hospitais, que adotavam estratégias como as descritas pela narradora. Os estudantes das faculdades de enfermagem podiam se filiar no último ano do curso e, desde então, eram instados a participar das atividades da associação.

${ }^{36}$ A ABEn por muito tempo aceitou a filiação exclusiva de enfermeiras ou de estudantes de enfermagem. Nos anos 1980, passou a aceitar os técnicos de enfermagem, e nos anos 1990, os auxiliares de enfermagem. As poucas escolas de enfermagem existentes no país até a década de 1970 eram principalmente públicas e com currículos propostos para horário diurno e integral, o que naturalmente selecionou candidatos de classe média para os seus vestibulares. Após a abertura de faculdades particulares, com turnos parciais e até noturnos, houve a abertura de possibilidade de ingresso de alunos trabalhadores, muitos deles já profissionais de enfermagem, em cursos de graduação nessa área. 
${ }^{37} \mathrm{O}$ uniforme distinguia a enfermeira dos demais profissionais de enfermagem, principalmente o uso da touca, que mais tarde foi abandonado na instituição em foco, justamente por ter perdido essa função.

${ }^{38}$ Clarice Ferrarini foi interlocutora de vários governadores de estado, num relacionamento que data do início de sua carreira, quando freqüentava o palácio do governo para assistir a familiares enfermos da personagem citada. Depois cultivou outros relacionamentos profissionais com políticos que sempre se trataram no Hospital das Clínicas da FMUSP, uma referência nacional que compreende os institutos do Coração, Central e de Ortopedia, entre outros.

${ }^{39}$ A sala da diretora de enfermagem ficava estrategicamente localizada no andar da entrada principal e em situação que permitia observar toda a movimentação de pessoas e também ser observada. Assim, se estabeleceu como um ponto de encontro e de reunião informal de diversas categorias profissionais, cuja posição hierárquica se alternava conforme o horário. Analogamente, consistia um local de confluência e distribuição da informação. A importância política da enfermeira diretora naquela época potencializava essa ação.

\section{REFERÊNCIAS BIBLIOGRÁFICAS}

Carvalho, Anayde

Correa de

$$
1976
$$

Cherubin, Niversindo

Antonio et al.

1999

Gattaz, André

Castanheira

1996

Janotti, Maria de

Lourdes Mônaco

1996

Neme, Bussâmara

abr.-jun. 1969

Sanna, Maria Cristina

1999
Associação Brasileira de Enfermagem 1926-1976. Documentário.

Brasília, ABEn, 514p.

Administração bospitalar. Fundamentos.

São Paulo, Cedas.

'Lapidando a fala bruta: a textualização em história oral'.

Em José Carlos Sebe B. Meihy (org.), (Re)introduzindo a bistória oral no Brasil. São Paulo, Xamã, cap. 13, pp. 135-40.

'Refletindo sobre história oral: procedimentos e possibilidades'.

Em José Carlos Sebe B. Meihy (org.), (Re)introduzindo a história oral no Brasil. São Paulo, Xamã, cap. 6, pp. 56-70.

'Enfermeira do Ano 1968'.

Maternidade e Infância, 28:2, pp. 69-70.

Histórias de enfermeiras gerentes: subsidios para a compreensão de um modelo referência de organização de serviços de enfermagem no período de 1950 a 1980. Tese de doutoramento, São Paulo, Escola de Enfermagem, Universidade de São Paulo. (mimeo.) 